\title{
Evolving Images
}


Exploring Jewish Arts and Culture Robert H. Abzug, Series Editor Director of the Schusterman Center for Jewish Studies 


\section{Evolving Images}

\section{Jewish Latin American Cinema}

EDITED BY NORA GLICKMAN AND ARIANA HUBERMAN

University of Texas Press $\underset{\sim}{\longrightarrow}$ Austin 
Our thanks to Robert H. Abzug, series editor for the University of Texas Press, for his support.

Copyright $\odot 2018$ by the University of Texas Press

All rights reserved

Printed in the United States of America

First edition, 2018

Requests for permission to reproduce material from this work should be sent to:

Permissions

University of Texas Press

P.O. Box 7819

Austin, TX $78713-7819$

utpress.utexas.edu/rp-form

(2) The paper used in this book meets the minimum requirements of ANSI/NISO Z39.48-1992 (R1997) (Permanence of Paper).

\section{Library of Congress Cataloging-in-Publication Data}

Names: Glickman, Nora, editor. | Huberman, Ariana, editor.

Title: Evolving images : Jewish Latin American cinema / edited by Nora Glickman and Ariana Huberman.

Other titles: Exploring Jewish arts and culture.

Description: First edition. | Austin : University of Texas Press, 2017. | Series: Exploring Jewish arts and culture | Filmography | Includes bibliographical references and index.

Identifiers: LCCN 2017018506 ISBN 978-1-4773-1426-5 (cloth : alk. paper)

ISBN 978-1-4773-1471-5 (pbk. : alk. paper)

ISBN 978-1-4773-1427-2 (library e-book)

ISBN 978-1-4773-1428-9 (non-library e-book)

Subjects: LCSH: Jews in the motion picture industry. | Motion pictures-Latin

America-2oth century. | Jews-Latin America-Identity.

Classification: LCC PN1995.9.J46 E95 2017 | DDC 791.43/652992408-dc23

LC record available at https://lccn.loc.gov/2017018506

doi:10.7560/314265 